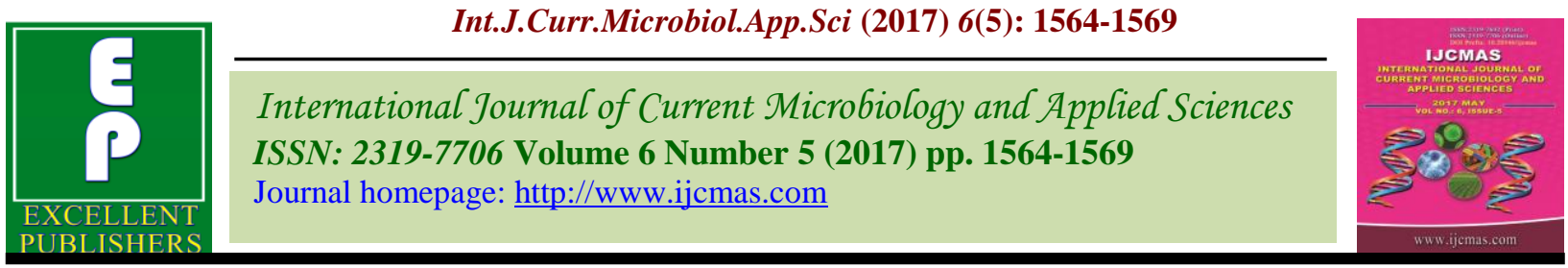

Original Research Article

https://doi.org/10.20546/ijcmas.2017.605.170

\title{
Survey for the Incidence of Root Rot/Wilt of Fenugreek in Northern Karnataka, India
}

\author{
N. Rani* and Yashoda R. Hegde \\ Department of Plant Pathology, University of Agricultural Sciences, \\ Dharwad-580005, Karnataka, India \\ *Corresponding author
}

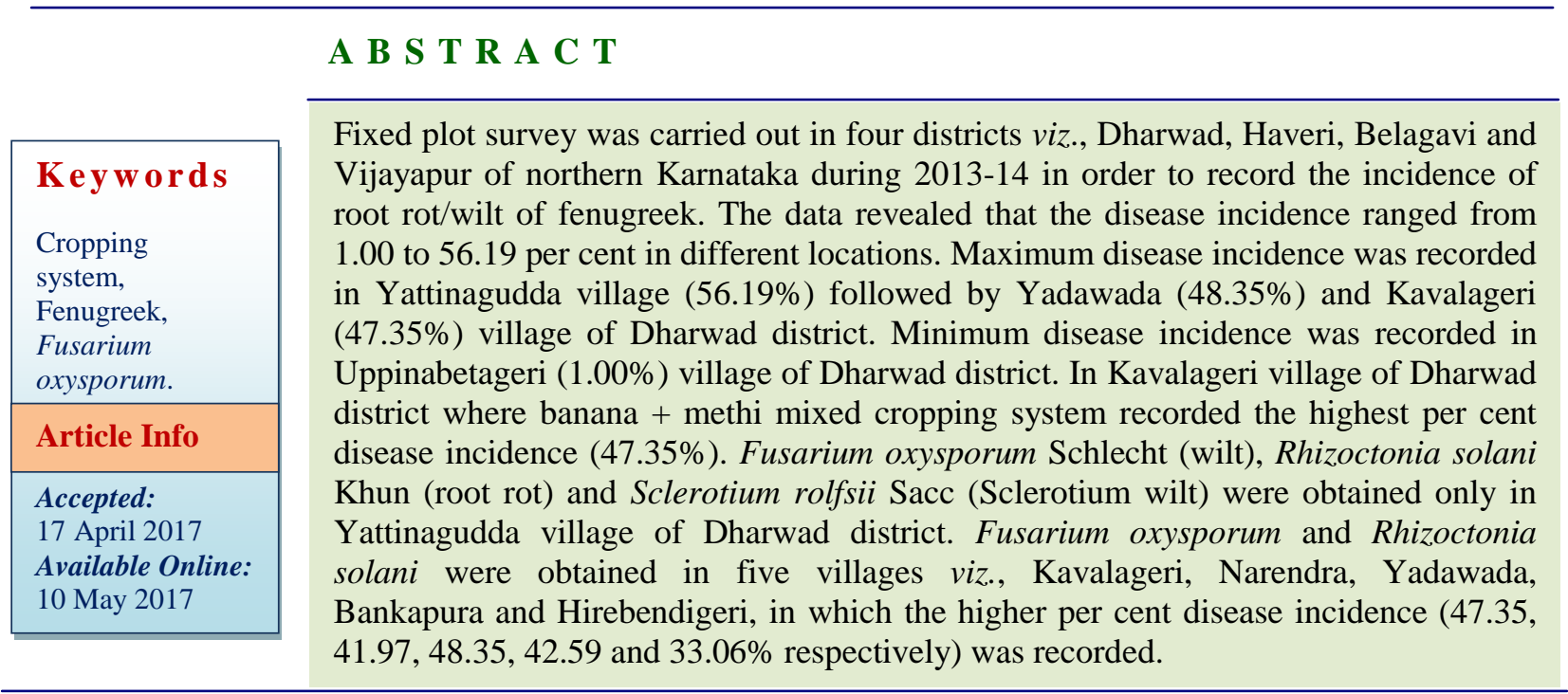

\section{Introduction}

Fenugreek (Trigonella foenum graecum L.) is an important seed spice, originated in SouthEastern Europe belonging to the family Fabaceae. It is a native of India and leading fenugreek producing country in the world. It is the third largest seed spice in India after coriander and cumin. In India, it is grown in about 66,000 ha with an annual production of about 90,000 tonnes (Anon., 2014). Rajasthan is the fenugreek bowl of country, contributing 90 per cent to the country's production. It has some pharmacological properties such as antitumor, antiviral, antimicrobial, antiinflammatory, hypotensive and antioxidant activity (Kor and Moradi, 2013). Fenugreek is mainly grown as leafy vegetable throughout
Karnataka and there is ample scope for its cultivation as seed spice. But fenugreek suffers from many of fungal diseases viz., Cercospora leaf spot caused by Cercospora traversiana, root rot (Rhizoctonia solani), leaf spot (Ascochyta sp.), powdery mildew (Erysiphe polygoni), downy mildew (Peronospora trigonellae) and Fusarium wilt (Fusarium oxysporum) (Prasad et al., 2014). The present study is concerned with one of the major diseases of fenugreek called wilt complex caused by the fungi like Fusarium oxysporum, Rhizoctonia solani and Sclerotium rolfsii. For the first time in India, Shivpuri and Bansal (1987) reported the Fusarium oxysporum Schlecht as the causal 
agent of wilt of fenugreek from Jaipur district of Rajasthan. Although many diseases are reported in fenugreek, wilt is becoming more severe in recent years. However no study has been conducted on this disease in Karnataka, so survey was conducted to know the per cent disease severity in northern Karnataka to identify hot spots for root rot/wilt of fenugreek.

\section{Materials and Methods}

Per cent Disease Incidence $=\quad \frac{\text { Number of plants infected }}{\text { Total number of plants observed }} \times 100$

The observations recorded such as per cent disease incidence, cropping system and pathogens associated with the disease are presented in table 1.

\section{Results and Discussion}

The data on survey revealed that the disease incidence ranged from 1.00 to 56.19 per cent in different locations. Maximum disease incidence was recorded in Yattinagudda village $(56.19 \%)$ followed by Yadawada $(48.35 \%)$ and Kavalageri (47.35\%) village of Dharwad district. Hence these places can be considered as 'hot spots' of fenugreek root rot/wilt disease. Minimum disease incidence was recorded in Uppinabetageri (1.00\%) village of Dharwad district. Among the districts surveyed, the mean maximum disease incidence $(27.28 \%)$ was recorded in Dharwad district followed by Haveri $(24.01 \%)$ and the mean least incidence $(17.66 \%)$ was noticed in Vijayapur district of Karnataka (Plate 1).

Three pathogens viz., Fusarium oxysporum (wilt), Rhizoctonia solani Khun (root rot) and Sclerotium rolfsii Sacc (Sclerotium wilt) were obtained only in Yattinagudda village of Dharwad district. Both Fusarium oxysporum
Intensive fixed plot survey was conducted during Kharif, 2014 to know the severity of root rot/wilt of fenugreek in Dharwad, Belagavi, Haveri and Vijayapur districts. In Dharwad, Belagavi, Haveri and Vijayapur district; ten, five, five and three villages and markets were surveyed respectively in these districts. The per cent disease incidence in the fields and market was assessed with the following formula. and Rhizoctonia solani were obtained in five village viz., Kavalageri, Narendra, Yadawada, Bankapura and Hirebendigeri, in which the higher per cent disease incidence (47.35, $41.97,48.35,42.59$ and $33.06 \%$ respectively) was recorded. Only Fusarium oxysporum was obtained in remaining villages and least per cent disease incidence was recorded as compared to combination of pathogens. In Vijayapur district, Indi village recorded the least disease incidence which may be due to the presence of mycophagous nematode (Aphelenchus sp.) which was feeding on the fungus Fusarium oxysporum.

The disease incidence varied from locality to locality, because of cropping pattern, environmental conditions, soil type and build up of inoculum. The higher disease incidence may be attributed to previous crop, complex nature of pathogen, monocropping system which may have aggravated the disease situation. Similar results were reported by Rani et al., 2014 in wilt of fenugreek caused by Fusarium oxysporum. The severity of the disease varied in different cropping systems. The maximum disease incidence was recorded in monocropping $(25.20 \%)$ followed by mixed cropping (24.86\%). 
Table.1 Survey for root rot/wilt of fenugreek during Kharif, 2014

\begin{tabular}{|c|c|c|c|c|c|c|}
\hline Districts & Taluk & Villages & Previous crop & Cropping system & Pathogens & PDI \\
\hline \multirow{10}{*}{ Dharwad } & \multirow{10}{*}{ Dharwad } & Govinkoppa & Methi & Monocropping & $\mathrm{F}$ & 23.99 \\
\hline & & Hebballi & Methi & Monocropping & $\mathrm{F}$ & 15.00 \\
\hline & & Kamalapura & Methi & Monocropping & $\mathrm{F}$ & 16.08 \\
\hline & & Kavalageri & Banana & Banana + Methi & $\mathrm{F}, \mathrm{R}$ & 47.35 \\
\hline & & Madihal & $\begin{array}{c}\text { Methi } \\
+ \text { Amaranthus }\end{array}$ & $\begin{array}{c}\text { Methi }+ \text { Coriander }+ \\
\text { Dill }\end{array}$ & $\mathrm{F}$ & 12.57 \\
\hline & & Narendra & Cotton & Methi + Soybean & $\mathrm{F}, \mathrm{R}$ & 41.97 \\
\hline & & Shibaragatti & Cucumber & $\begin{array}{c}\text { Methi }+ \text { Cucumber }+ \\
\text { Coriander }\end{array}$ & $\mathrm{F}$ & 10.29 \\
\hline & & Uppinabetageri & Sorghum & Monocropping & $\mathrm{F}$ & 1.00 \\
\hline & & Yadawada & Methi & Monocropping & $\mathrm{F}, \mathrm{R}$ & 48.35 \\
\hline & & Yattinagudda & Methi & Monocropping & $\mathrm{F}, \mathrm{R}$ and $\mathrm{S}$ & 56.19 \\
\hline \multicolumn{6}{|c|}{ District mean } & 27.28 \\
\hline \multirow{5}{*}{ Haveri } & \multirow{5}{*}{ Shiggavi } & Bankapura & Methi & Monocropping & $\mathrm{F}, \mathrm{R}$ & 42.59 \\
\hline & & Ganjigatti & Cotton & Cotton + Methi & $\mathrm{F}$ & 17.21 \\
\hline & & Hirebendigeri & Methi & Monocropping & $\mathrm{F}, \mathrm{R}$ & 33.06 \\
\hline & & Hiremallur & Methi & Monocropping & $\mathrm{F}$ & 11.32 \\
\hline & & Subaragatti & Methi & Monocropping & $\mathrm{F}$ & 15.88 \\
\hline \multicolumn{6}{|c|}{ District means } & 24.01 \\
\hline \multirow{5}{*}{ Belagavi } & \multirow{5}{*}{ Bailahongala } & Bailahongala & Methi & Monocropping & $\mathrm{F}$ & 29.22 \\
\hline & & Hanabarahatti & Groundnut & Maize +Methi & $\mathrm{F}$ & 19.77 \\
\hline & & Madanabavi & Methi & Monocropping & $\mathrm{F}$ & 22.87 \\
\hline & & Nesergi & Methi & Monocropping & $\mathrm{F}$ & 9.70 \\
\hline & & Somanahatti & Methi & Monocropping & $\mathrm{F}$ & 25.88 \\
\hline \multicolumn{6}{|c|}{ District mean } & 21.49 \\
\hline \multirow{3}{*}{ Vijaypur } & \multirow{3}{*}{ Indi } & Atharga & Methi & Monocropping & $\mathrm{F}$ & 20.75 \\
\hline & & Indi & Methi & Monocropping & F, Mycophagous & 14.67 \\
\hline & & Nagatana & Methi & Monocropping & $\mathrm{F}$ & 17.57 \\
\hline \multicolumn{6}{|c|}{ District mean } & 17.66 \\
\hline
\end{tabular}

F- Fusarium oxysporum $\quad$ R- Rhizoctonia solani

S- Sclerotium rolfsii 
Plate.1 Survey for root rot/wilt of fenugreek in Northern Karnataka

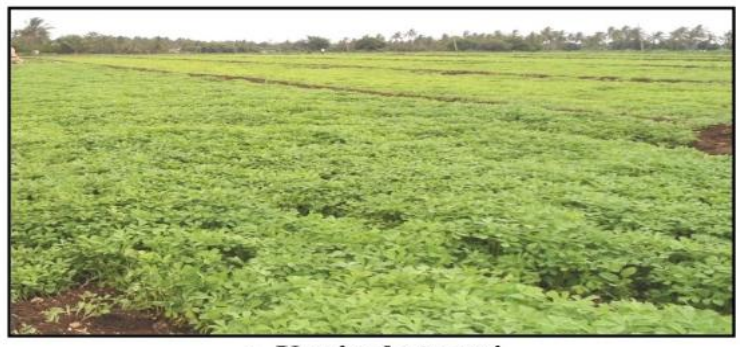

a. Uppinabetageri

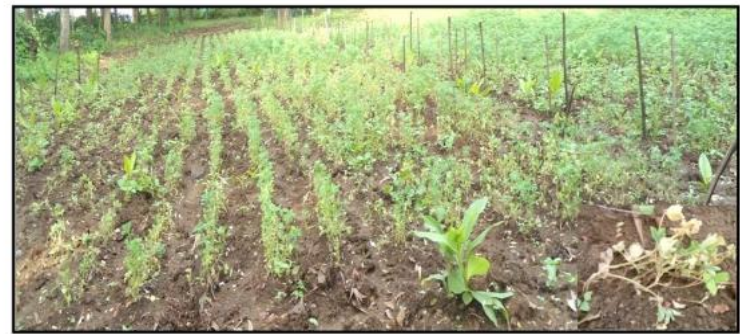

b. Yattinagudda (seedling stage)

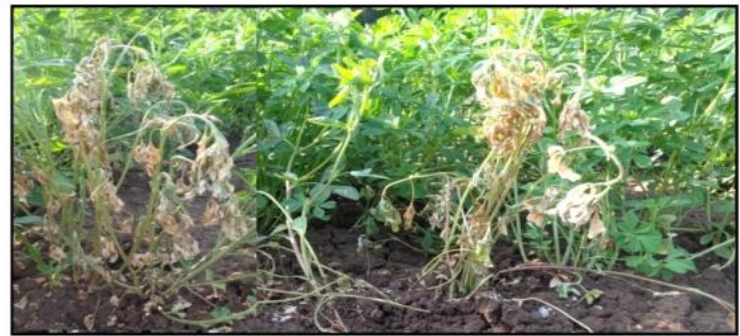

c. Yattinagudda (Flowering stage)

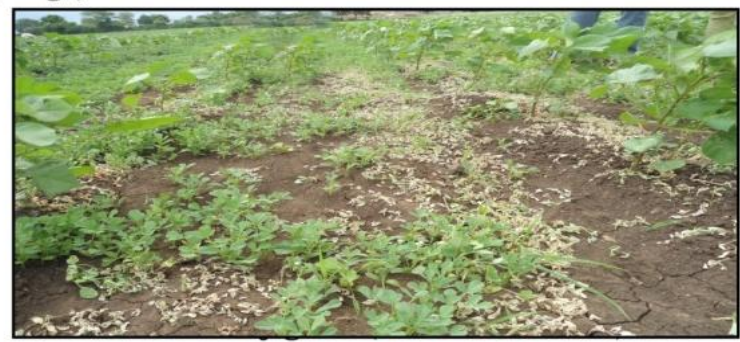

d. Ganjigatti (cotton + methi )

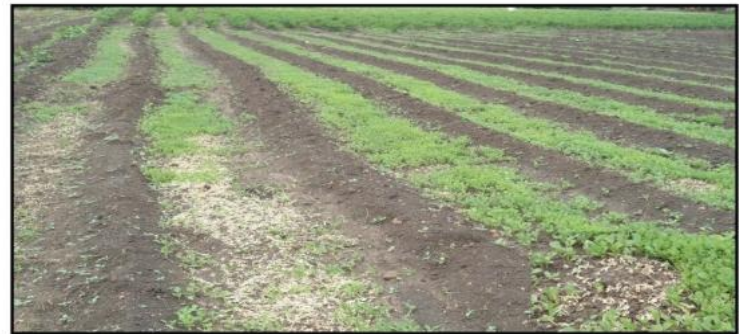

e. Yadawada 
Table.2 Effect of cropping system on per cent disease incidence of root rot/wilt of fenugreek

\begin{tabular}{|c|c|c|c|}
\hline \multicolumn{2}{|c|}{ Cropping system } & Name of the villages & PDI \\
\hline \multirow{16}{*}{\multicolumn{2}{|c|}{ Sole cropping }} & Atharga & 20.75 \\
\hline & & Bailahongal & 29.22 \\
\hline & & Bankapura & 42.59 \\
\hline & & Govinakoppa & 23.99 \\
\hline & & Hebballi & 15.00 \\
\hline & & Hirebendigeri & 33.06 \\
\hline & & Hiremallur & 11.32 \\
\hline & & Indi & 14.67 \\
\hline & & Kamalapura & 16.08 \\
\hline & & Madanabavi & 22.87 \\
\hline & & Nesergi & 9.70 \\
\hline & & Ngatana & 17.57 \\
\hline & & Somanahatti & 25.88 \\
\hline & & Subaragatti & 15.88 \\
\hline & & Yattinagudda & 56.19 \\
\hline & & Mean & 25.20 \\
\hline \multirow{7}{*}{ Mixed cropping } & Cotton + Methi & Ganjigatti & 17.21 \\
\hline & Maize +Methi & Hanabarahatti & 19.77 \\
\hline & Banana + Methi & Kavalageri & 47.35 \\
\hline & Methi + Coriander + Dill & Madihal & 12.57 \\
\hline & Methi + Soybean & Narendra & 41.97 \\
\hline & Methi + Cucumber + Coriander & Shibaragatti & 10.29 \\
\hline & & Mean & 24.86 \\
\hline
\end{tabular}

In Kavalageri village of Dharwad district where banana + methi mixed cropping system recorded the highest per cent disease incidence $(47.35 \%)$. It may be due to similar host range of pathogen lead to severity of the disease. Whereas in Shibaragatti village of Dharwad district, methi + cucumber + coriander mixed cropping system recorded lowest per cent disease incidence (10.29\%) (Table 2). However, there was no much clear cut difference in incidence of wilt with respect to cropping system. Environmental conditions play an important role in increasing the severity of disease. The least disease incidence was recorded in mono cropping system in Uppinabetageri $(1.00 \%)$ where in previous crop was sorghum, root exudates of sorghum may have reduced the inoculum load, leading to least disease incidence. These results are in conformity with the findings of Naik et al., 1996 in case of $F$. udum, where in pigeonpea was intercropped with sorghum followed by sorghum sequenced with safflower however, Shalini and Kulkarni (2008) recorded the higher disease incidence of ginger rhizome rot in continuous monocropping system.

Continuous monocropping, previous crops grown, complex nature of pathogen lead to the buildup of inoculum of the pathogen in the soil over the seasons especially the population of Fusarium oxysporum. When there is an optimum soil temperature and moisture caused more damage to the crop. In some places, there was association of 
Fusarium oxysporum, Rhizoctonia solani and Sclerotium rolfsii resulting in wilt complex similar findings were recorded by Ravichandran et al., 2014 in chickpea wilt complex. Sclerotium rolfsii was observed only from Yattinagudda village of Dharwad district. This is the first report of Sclerotium rolfsii in fenugreek. The Sclerotium wilt symptoms appeared as yellowing or wilting of the lower leaves. Growth of the fungus was observed at collar region of the plant with white cottony mycelium. The fungus spread more rapidly and destroyed the root system leading to death of plant. In severe cases, pathogen produced the sclerotia on the infected tissues. Sclerotium rolfsii as a casual agent of Sclerotium wilt of fenugreek was proved by pathogenicity study, plants were observed for symptoms development. The symptoms produced were similar to the symptoms as described above. Death of seedlings was noticed at 18 days after sowing. These observations are in agreement with the earlier descriptions given by Rani et al., 2014.

\section{References}

Anonymous. $2014 . \quad$ India Stat.www.indiastat.com.

Kor, N.M. and Moradi, K. 2013. Physiological and pharmaceutical effects of fenugreek (Trigonella foenum-graecum) as a multipurpose and valuable medicinal plant. Glob. J. Med. Pl. Res., 1: 199-206.

Naik, M.K., Reddy, M.V., Raju, T.N. and Rego, T.J. 1996. Pigeonpea production systems in relation to sustainable management of Fusarium wilt. In: Studies in Indian Agroecosystem, (Ed. Pathak, P. S. and Goel, B.), National Institute of Ecology, New Delhi, pp. 4550.

Prasad, R., Acharya, S., Erickson, S, and Thomas, J. 2014. Identification of cercospora leaf spot resistance among fenugreek accessions and characterization of the pathogen. Australian J. Crop. Sci., 8(6): 822-830.

Rani, N., Hegde, Y.R., Nargund, V.B., Lingaraju, S. and Nagangowda, S.B. 2014. Scenario of wilt complex of fenugreek and its management. Nation. Symp. Plant diseases: New perspectives and innovative management strategies. 5. Epidemiology in relation to climate change, 11-12, December, 2014, UAS, Dharwad (India), p. 33.

Ravichandran, S., Hegde, Y.R., Ganajaximath, and Uppinal, N.F. 2014 Survey for chickpea wilt complex in northern Karnataka. Nation. Symp. Plant diseases: New perspectives and innovative management strategies, 5. Epidemiology in relation to climate change, 11-12, December, 2014, UAS, Dharwad (India), p. 29.

Shalini, D.S. and Kulkarni, S. 2008. Survey, surveillance and etiology of rhizome rot of ginger in Karnataka. J. Pl. Dis. Sci., 3(1): 37-39.

Shivpuri, A. and Bansal, P.K. 1987. Fusarium wilt of Trigonella foenum-graecum L. Indian J. Mycolo. Pl. Pathol., 26: 749751.

\section{How to cite this article:}

Rani, N., and Yashoda R. Hegde. 2017. Survey for the Incidence of Root Rot/Wilt of Fenugreek in Northern Karnataka, India. Int.J.Curr.Microbiol.App.Sci. 6(5): 1564-1569. doi: https://doi.org/10.20546/ijcmas.2017.605.170 